\title{
Dinamika Online Persona Akun Anonim Twitter Penggemar KPop
}

\author{
Kirana Wistiani Ayundari \\ | Mahasiswa Prodi S1 Departemen Ilmu Komunikasi, FISIPOL, UGM \\ Bisa dihubungi melalui email kiranatia95@gmail.com \\ Pulung S. Perbawani \\ | Staff pengajar Departemen Ilmu Komunikasi, FISIPOL UGM. Bisa dihubungi melalui \\ email psperbawani@ugm.ac.id
}

\section{ABSTRAK}

This article addresses the psychological aspect of the need for comfort and freedom of self expression amomg KPop fans, which actualized through anonym account on twitter. KPop is one of the so-called interest which has some activities that always being compared to fanatism and still can't be accepted freely to general public. As part of the minorities, KPop fans are seeking for a place that could give them freedom for presenting their identites as fans who are actively participating in KPop fandom activities, and that place is none other than using pseudonym account on Twitter.

A survey of 400 respondents who are using KPop anonym account on Twitter showed that privacy is the reason for 300 respondents to use anonymous accounts. The results of the mean test on the five dimensions of online persona variables are nickname (3.59), trust (3.78), online identification (3.44), grandiosity (3.09), and self-esteem (2.97). The results of the mean test on the group dynamics variable dimensions are connection (3.37), supportive interaction (3.07), affective (4.05), and cognitive (4.16). Seeking for a privacy and entertainment as a form of seperating themselves from face-to-face environment could give KPop fans to interact more about their KPop interests or even talking about their private lives through virtual environments, which is Twitter.

Through interactions by using pseudonym, there are times when KPop fans are not just talking about their KPop interests, but also showing their identities and also their private lives as a phase when they're interacting with other KPop fans. Therefore, these could lead to an enchancement where solidarity are felt within KPop fandom in Twitter, and this could also give each KPop fans the feeling of being accepted and feeling lucky when they couldn't present themselves freely in a real life before and here they become more open and happy on this Twitter environment.

Keyword: anonymity, kpop, privacy, new media psychology, social media, Twitter

\section{Pendahuluan}

Munculnya internet memberikan dampak kepada manusia dalam menghabiskan waktunya di dunia virtual. Di sini, para individu akan menghabiskan waktu sendiri dengan teknologi dan menghabiskan sebagian besar waktu mereka dalam jejaring. Dunia virtual menjadi sebuah wadah sosial di mana identitas sosial dan personal terbentuk dan perspektif ini menjadikan keinginan individu dalam berkomunikasi terbagi oleh dunia nyata dan virtual (Gackenbach, 2007, hal.72; Stahl dalam Williams, 2006, hal.21-23). Ini dapat membuat seseorang mulai hidup di realita buatan yang memberikan lebih sedikit tempat untuk memiliki pengalaman tatap muka dengan orang lain dan bertemu seseorang secara langsung menjadi lebih canggung daripada berkomunikasi melalui videophone (Van Dijk, 2006, hal.206-207).

Dalam dunia virtual, media sosial menjadi tempat di mana para pengguna berpartisipasi dan saling berkomunikasi tanpa batasan waktu dan 
tempat, dan Twitter menjadi salah satu media sosial yang mengizinkan para penggunanya menggunakan identitas pseudonim, di mana identitas yang dibuat tidak mengharuskan penggunanya menghubungkan dengan informasi pribadi sehingga banyak pengguna Twitter tidak menyediakan dan memberikan opsi penggunanya untuk menggunakan informasi dari nama asli, biodata, hingga foto profil pada saat menciptakan akun. Identitas pseudonim dalam Twitter ini kemudian menjadi wadah seseorang untuk mencurahkan isi hatinya dan menjadikannya sebagai ruang privasi yang menjaga informasi pribadinya dari dunia nyata.

Internet menyediakan lingkungan anonim yang memungkinkan seseorang untuk berperilaku sesuai dengan diri mereka yang sebenarnya (true self) karena berkurangnya rasa takut akan ketidaksetujuan dari orang lain di dunia nyata ( $\mathrm{Hu}$ dkk., 2017 dalam Hu dkk, 2020, hal. 214). Mereka ingin merasa lebih nyaman dalam berinteraksi dengan orang-orang yang memiliki ketertarikan yang sama dan terbebas dari tekanan sosial yang menghambat mereka melakukan apa yang sebenarnya diinginkan. Tekanan sosial tersebut bisa saja dari kerabat di dunia nyata, baik keluarga maupun teman, di mana mereka tidak ingin orangorang di dunia nyata memiliki hubungan dengannya saat berada di dunia virtual.

Di titik inilah seseorang membutuhkan privasi sebagai bentuk kebebasan. Privasi inilah yang dinamakan anonimitas. Kondisi anonimitas dapat mendorong seseorang untuk mengungkapkan informasi pribadinya secara lebih bebas yang disebabkan karena mereka merasa tidak perlu dibatasi oleh harapan orang lain atau lebih sedikit kemungkinan untuk merasakan sanksi sosial (Ma dkk, 2017, hal.1782). Anonimitas ini kemudian memberikan efek yang disebut Suler sebagai 'online disinhibition', di mana seseorang dapat bertindak berbeda di dunia virtual daripada komunikasi tatap muka. Online disinhibition effect dapat memperkecil kekangan sosial dan memberikan kesempatan seseorang untuk berbicara secara bebas ketika berada di dunia virtual yang kemudian memberikan rasa kedekatan para individu ketika. Bagi Joinson, disinhibition effect ini dikarakteristikan sebagai menurunnya tingkat kegelisahan terhadap presentasi diri dan penghakiman dari orang sekitar di lingkungan tatap muka (Gackenbach, 2007, hal. 92; Lee, dkk., 2014, hal.2-3; Attrill \& Fullwood, 2016, hal.169).

Seseorang dapat menggunakan anonimitas untuk menjadi seseorang yang berbeda di dunia virtual tanpa takut teridentifikasi dan secara negatif dihakimi oleh mereka yang sudah dikenal di dunia nyata. Mereka memilih untuk menjadi anonim meliputi berpura-pura menjadi orang lain atau memiliki identitas fiksional, yang kemudian disebut sebagai pseudonimitas. Anonimitas kemudian dimanfaatkan oleh suatu aplikasi yang dikenal sebagai media sosial. Media sosial memainkan kombinasi sebuah efek imajinatif dengan kisah kehidupan nyata yang di dalamnya seseorang dapat memainkan peran di mana identitas aslinya tidak dikenali.

Menurut Keipi, dkk. (2014, hal.3-7), pengaturan anonimitas dalam interaksi online ini mengizinkan penggunanya sebuah fleksibilitas yang selama ini diinginkan, serta kebebasan untuk menampilkan persona. Dalam sebuah penelitian 
oleh Wallace dan Keipi, dkk (1999, hal.14-36; 2014, hal.5), di mana seseorang ingin membentuk sebuah online persona untuk memberikan kesan (impression) dalam mempresentasikan dirinya sesuai dengan apa yang menurut mereka tepat atau sesuai. Boyle dan Johnson menyatakan bahwa lingkungan virtual memberikan kesempatan untuk penggunanya dalam menyesuaikan self-presentation yang diinginkan kepada pengguna lain melalui memilih aspek dari diri (self) apa yang ingin ditutupi dan ditunjukan (2010, hal.2-6). Seseorang dapat menciptakan online persona yang baru melalui konstruksi identitas virtual dan dengan berada di lingkungan virtual, seseorang dapat lebih fleksibel dibandingkan dengan dunia offline (nyata) (Hussain dan Griffiths dalam Attrill dan Fullwood, 2016: 209; Schau dan Gilly dalam Lee, dkk. 2014: 3; Hogan, 2012: 65-66). Rekonstruksi identitas virtual di situs jejaring sosial dapat memenuhi kebutuhan seseorang untuk menyembunyikan karakteristik yang tidak diinginkan dan hanya menyediakan informasi yang telah dipilih sehingga individu dapat menunjukkan identitas yang sempurna (Huang, Kumar, \& Hu, 2018, hal 593).

Muncul sebuah polemik terkait identitas yang berhubungan dengan privasi, di mana bahasan privasi mungkin terlihat ironis ketika salah satu memandang seseorang yang berada di media sosial mempublikasikan kehidupannya secara terbuka. Pseudonim tidak hanya digunakan sebagai keperluan kepemilikan (authorship), tetapi juga sebagai penutup identitas dari dunia nyata. Alasan yang paling sering menjadi latar belakang di balik pemakaian pseudonim adalam menyembunyikan identitas media sosial dari keluarga, teman, dan rekan kerja, di mana salah satunya untuk menjaga privasi keluarga dan tidak menginginkan identitas media sosialnya muncul di dalam mesin pencari. Mereka ingin menciptakan jarak antara identitas virtualnya dengan diri mereka sehari-hari.

Anonimitas membuka kesempatan untuk seseorang dalam bermain dengan identitasnya, mereka membentuk identitas baru sebagai pengekspresian 'true selves' mereka yang selama ini dipendam di lingkungan nyata. Menggunakan berbagai nama samaran (pseudonim), seseorang dapat bertukar opini atau informasi tanpa memperlihatkan identitas asli mereka dan mereka dapat menghilangkan topeng dunia nyata mereka dan lebih memperlihatkan dirinya di dunia virtual.

Hal ini yang kemudian menjadikan fans memiliki hubungan kuat dengan penggunaan anonimitas di media sosial. Bury dkk. dalam jurnal milik Heglingegard (2016: 12) mempelajari adanya pengaruh media sosial terhadap budaya fan (fan culture) dan bagaimana media sosial mengubah dunia fandom. Fans lebih memilih untuk menggunakan media sosial yang memperbolehkan mereka tampil anonim karena mereka tidak selamanya ingin berbagi kegemaran atau fakta ke teman dan keluarganya bahwa mereka adalah anggota aktif dari suatu fandom. Fans menggunakan media sosial untuk berkomunikasi dengan sesamanya dalam sebuah fandom (subkultur) yang memiliki perilaku dan kepercayaan berbeda dari budaya dominan, dan mereka menggunakan anonimitas untuk memberikan kesempatan para fans secara bebas berkomunikasi terhadap sesamanya.

Jenkins dalam Textual Poachers (1992) 
menyatakan bahwa fans bukan sekadar audiens, namun mereka mampu menerjemahkan objek yang mereka sukai ke dalam berbagai kegiatan kultural, seperti berdiskusi mengenai konten bersama teman dan bergabung dalam komunitas yang memiliki ketertarikan yang sama. Hal ini kemudian dapat digambarkan bahwa fans merupakan sosok yang memiliki ikatan emosional dengan objek yang disenangi dan mewujudkannya dengan berdiskusi mengenai konten serta bergabung dengan komunitas fans (fandom). Alasan utama para fans berpartisipasi dalam suatu fandom adalah untuk menemukan tempat di mana aktivitas "fanatik" mereka dapat diterima. Menurut Obiegbu dkk (2019, hal.467) fandom dikonstruksikan sebagai ekspresi kesetiaan yang tinggi terlepas dari jenis merek yang dikaitkan dengannya.

Fandom virtual ini memungkinkan berbagai orang untuk berinteraksi tanpa dihakimi latar belakang sosial, ras, atau status ekonomi, melainkan mereka lebih mencari manfaat dari komitmennya tergabung dalam fandom, di mana para fans dapat membentuk rasa solidaritas diantaranya yang memiliki persamaan minat. Seperti yang dijelaskan oleh Williams, bahwa hubungan antara penggemar "dapat berkembang menjadi persahabatan yang melampaui kesamaan minat, menawarkan dukungan emosional dan menggantikan keberadaan objek penggemar itu sendiri" (2015, hal.25).

Dari berbagai fandom yang ada, fandom KPop adalah salah satu fandom terbesar yang memiliki hubungan kuat dengan media sosial. Dalam penelitiannya mengenai KPop, fandom Indonesia, dan media sosial, Jung (2011) menjelaskan bahwa banyak fans yang menunjukkan dirinya membangun jaringan, terutama jaringan internasional, melalui fandom KPop berbasis media sosial. Twitter sebagai sumber terpenting untuk informasi dan distribusi KPop diantara populasi anak muda, terutama di Indonesia (survei dari Lee, 2012, hal.4-5). Fandom KPop sebagai fandom terunik, terorganisir, dan kolektif memiliki obsesi sendiri, di mana fans menciptakan, mendistribusikan, dan mempromosikan baik media official dari artis KPop-nya tersebut (akun perusahan yang menaungi para artis atau akun pribadi artis KPop) dan konten-konten yang dibuat oleh para fans di internet. Penelitian ini ingin melihat proses komunikasi yang melihat dari segi aspek psikologis seseorang di balik pemakaian akun pseudonim dalam gambaran diri di Twitter. Twitter menjadi salah satu sumber terpenting untuk informasi dan distribusi KPop di antara anak muda Indonesia. Mereka menjadikan media Twitter, sebagai tempat membentuk komunitas fan dan bagaimana kemudian mereka membentuk sebuah fandom KPop melalui media sosial ini.

Dalam fandom Kpop, salah satu aspek yang menonjol adalah adanya group dynamics yang kuat dan unik. Menurut Wallace, seseorang juga ingin menciptakan hubungan yang kuat dengan orang lain dalam sebuah kelompok ketika berada di dunia virtual daripada di dunia nyata, di mana dia menjelaskannya sebagai group dynamics, yaitu bagaimana seseorang mencari sebuah komunitas atau kelompok orang yang memiliki minat atau tujuan yang sama (1999, hal.151). Dalam hal ini individu dapat mencari koneksi atau bahkan mengeksplorasi hubungan baik antar individu atau 
melalui komunitas yang dibuat dalam sebuah group dynamics di media sosial.

Group dynamics dipengaruhi dengan adanya rasa kepemilikan (sense of belonging) dan komitmen (commitment). Sense of belonging dapat dikaitkan dengan bagaimana seseorang ingin merasa diterima dan mendapatkan ikatan dalam komunitasnya. Sense of belonging dapat diukur melalui connection dan supportive interaction, di mana connection adalah keinginan untuk mengoneksikan diri dengan orang lain hingga seseorang dapat memiliki rasa penting adanya hubungan dengan orang lain, sedangkan supportive interaction dapat mengikutsertakan pengguna media sosial dalam interaksi dukungan (seperti saling berbagi informasi, memberikan semangat, dan memperlihatkan ketertarikannya) yang kemudian dapat mendukung self-esteem seseorang (Chen: 2010, hal.2-4; Oh, dkk: 2013, hal.1-6). Sedangkan commitment digambarkan sebagai seseorang yang terhubung dengan sekelompok orang dalam lingkungan virtual mungkin akan menjadi lebih kuat ikatannya daripada mereka yang terhubung dalam kelompok realita tatap muka. Commitment dapat diukur melalui penelitian yang dilakukan oleh Cheung, dkk. (2010,hal.3) yang melibatkan identitas sosial yang kuat, di mana peningkatan komitmen dapat terjadi ketika seseorang berbagi minat atau tujuan yang sama dengan pengguna lain di media sosial.

\section{METODE}

Penelitian yang melatarbelakangi artikel ini dilaksanakan menggunakan pendekatan kuantitatif dengan metode survei. Populasi dalam penelitian ini adalah pengguna Twitter di Indonesia yang memiliki akun anonim KPop. Sampel sebesar 400 responden dipilih dari mereka yang lolos pertanyaan diskriminan yang membedakan layak atau tidaknya menjadi sampel yaitu 1) Pengguna Twitter, 2) Merupakan fans KPop yang aktif dalam fandom KPop di Twitter, dan 3) Menggunakan pseudonim selama berinteraksi di Twitter.

Instrumen penelitian berupa kuesioner disusun dengan berdasarkan kerangka konsep yang diilustrasikan pada tabel di bawah ini:

Tabel 1. Kerangka konsep penelitian

\begin{tabular}{|c|c|c|c|}
\hline \multirow{4}{*}{$\begin{array}{c}\text { Aspek } \\
\text { Psikologis } \\
\text { dalam Media } \\
\text { Sosial }\end{array}$} & \multirow[b]{2}{*}{$\begin{array}{l}\text { Online } \\
\text { persona }\end{array}$} & Impression & - Nickname \\
\hline & & $\begin{array}{l}\text { Self-presentation } \\
\text { (Keipi,dkk.) }\end{array}$ & 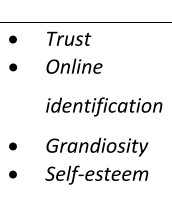 \\
\hline & \multirow[t]{2}{*}{$\begin{array}{c}\text { Group } \\
\text { dynamics }\end{array}$} & $\begin{array}{l}\text { Sense of Belonging } \\
\text { (Chen dan Oh, dkk.) }\end{array}$ & $\begin{array}{l}\text { - } \text { Connection } \\
\text { - Supporitve } \\
\text { Interaction }\end{array}$ \\
\hline & & $\begin{array}{l}\text { Commitment (Cheung, } \\
\text { dkk.) }\end{array}$ & $\begin{array}{l}\text { - Affective } \\
\text { - Cognitive }\end{array}$ \\
\hline
\end{tabular}

Sumber: penulis

Instrumen penelitian telah melewati proses penjaminan mutu, melalui uji validitas menggunakan Pearson Correlation Test, dan uji reliabilitas dengan menggunakan Cronbach Alpha. Pada hasil uji validitas, nilai tertinggi yang didapat ada pada 0.829 dan terendah adalah -0.302. Dengan demikian, semua butir pertanyaan yang digunakan dalam penelitian ini valid dan dapat digunakan sebagai instrumen penelitian karena 
nilai tersebut sudah memenuhi syarat di mana $0.829>0.239$ dan $-0.302<-0.239$. Dari hasil uji reliabilitas, diketahui bahwa nilai cronbach alpha adalah 0.955, maka dapat dipastikan bahwa pertanyaan dalam kuesioner penelitian ini sudah reliabel.

Analisis deskriptif yang digunakan untuk penelitian ini akan memanfaatkan analisis multiple response dan cross tabulation, di mana keduanya digunakan untuk menggambarkan responden dengan kecenderungan yang perlu untuk ditampilkan dalam penelitian ini. Multiple response adalah teknik analisis yang bisa digunakan untuk mengolah data di mana satu responden memberikan alternatif jawaban ataupun respons yang digunakan sebagai menentukan skala prioritas atau pilihan dari responden. Sedangkan crosstabs digunakan untuk menunjukkan tabulasi silang dari data yang ada sehingga dapat melihat kecenderungan polarisasi data (Purwanto dan Sulistyastuti, 2011: 123).

Hasil dari penelitian yang didapat membuktikan bahwa responden didominasi oleh perempuan, di mana sebanyak 385 responden (96\%) adalah perempuan, sedangkan hal ini berbanding sangat jauh dengan responden lakilaki yang hanya memenuhi hingga 15 responden (4\%) saja. Fans KPop yang aktif dalam penggunaan akun anonim KPop di Twitter berkisar dari kelompok usia 15-25 tahun, sedangkan tidak banyak dari kisaran usia di atas 25 tahun. Dalam kisaran kelompok usia 15-25 tahun tersebut dapat dilihat adanya dominasi dari usia 22 tahun dengan 67 responden (17\%). Profesi mayoritas adalah pelajar dan mahasiswa sebanyak 268 responden (69\%), dan karyawan swasta/BUMN/NGO, yaitu sebanyak 72 responden (18\%). Sebanyak 106 responden (26.5\%) sudah mulai menggunakan Twitter sejak tahun 2009 dan dilanjutkan dengan tahun 2010 dengan perbedaan yang tidak jauh, yaitu 88 responden (22\%). Hal ini membuktikan bahwa pada masa itu, fans KPop di Indonesia sudah mengenal Twitter.

\section{PEMBAHASAN}

\section{Aspek Anonimitas}

Terdapat beberapa hal yang mendorong seseorang menggunakan akun anonim, diantaranya adalah motivasi identitas, motivasi hiburan, motivasi sosial dan motivasi privasi. Gambar 1 menunjukkan motivasi responden menggunakan akun anonim.

Gambar 1. Motivasi pemakaian akun anonim

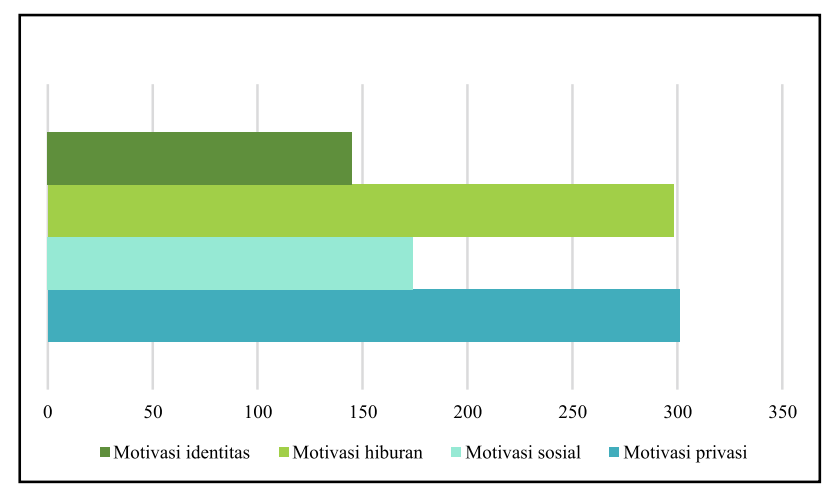

Sumber: Data kuesioner, diolah

Dari aspek Motivasi, privasi adalah motivasi yang paling dominan dijadikan oleh responden untuk menggunakan akun anonim di Twitter, dengan 300 responden yang menyatakan menggunakan akun anonim dengan alasan privasi. Hal ini menandakan bahwa pseudonimintas dipahami sebagai bentuk "proteksi" dari perasaan takut dihakimi orang lain atau berbagai prasangka yang selama ini berhubungan dengan minat KPop 
atau identitas pribadinya di dunia nyata. Responden dapat dipahami bahwa mereka ingin menghilangkan kekhawatiran mereka terhadap adanya kenalan, teman kerja, atau keluarga yang datang ke Twitter dan kemungkinan menemukan akun mereka. Hal ini menggambarkan bahwa responden memiliki keinginan untuk lebih bebas dalam berinteraksi dengan fans KPop lainnya atau sekadar melakukan kegiatan yang terkait dengan Kpop.

Selain sebagai privasi, responden juga mengakses Twitter melalui akun anonim untuk sebuah hiburan, baik itu sebagai escapism mereka dari penatnya kehidupan nyata atau sebagai bentuk relaksasi di waktu luang. Hal ini dapat berhubungan dengan motivasi privasi, di mana penggunaan akun anonim dapat memberikan pengaruh positif terhadap kesejahteraan psikologis responden karena adanya keinginan untuk mendapatkan hiburan dari pemakaian akun anonim. Selama seseorang menggunakan akun anonim untuk menjauhkan diri dari orang lain yang mereka kenal di dunia nyata, mereka menjadi lebih bebas untuk melakukan kegiatan fandom KPop yang mereka sukai dan menjadikan akun anonim sebagai bentuk relaksasi yang dapat memberikan kesejahteraan psikologis tersebut.

Pada aspek elemen anonimitas, mayoritas responden yang menggunakan akun anonim akan menutupi nama asli mereka di Twitter, baik itu nama depan atau nama belakang responden. Mereka memilih untuk menggunakan nama yang bagi mereka menarik dan tidak ada hubungannya dengan nama asli mereka atau menggunakan nama yang berkaitan dengan idola yang mereka gemari.
Selain pemakaian elemen profile nama palsu, mayoritas responden memilih bio dan header photo yang juga mereka samarkan. Ini dapat digarisbawahi bahwa penyamaran bukan berarti mereka sepenuhnya merekayasa identitas mereka, tetapi mereka lebih ingin memperlihatkan bahwa mereka adalah fans KPop yang tidak ingin menunjukkan identitas pribadi mereka. Sama halnya dengan penyamaran profile photo dan username yang juga merupakan elemen-elemen yang banyak dipilih responden sebagai bentuk penyamaran elemen profile Twitter mereka.

\section{Analisis Mean}

Analisis mean hanya dilakukan pada pertanyaan dengan model Likert yang bernilai 1 untuk menyatakan sangat tidak setuju dan 5 untuk menyatakan sangat setuju. Analisis mean akan melihat rata-rata dari dua variabel yang telah ditentukan, yaitu online persona dan group dynamics. Online persona akan diukur melalui impression dan self-presentation, dan group dynamics kemudian dihubungkan dengan konsep sense of belonging dan commitment.

Terdapat kecenderungan bahwa fans KPop yang menggunakan akun anonim lebih sering membicarakan mengenai KPop dibandingkan kehidupan pribadinya. Akan tetapi, selama menggunakan akun anonim mereka lebih banyak berbicara dan tidak menyembunyikan identitas pribadinya. Hal ini kemudian menjadikan adanya kecenderungan bahwa penggunaan akun anonim KPop dan bagaimana mereka mendapatkan teman baru serta saling berinteraksi mengenai 
minat KPop-nya memberikan perasaan beruntung. Melihat kecenderungan ini, dapat dilihat bahwa penggunaan akun anonim memberikan kebebasan fans KPop untuk memperlihatkan minat KPop-nya lebih bebas dan mendapatkan pengaruh positif selama berkomunikasi di dalamnya.

\section{Online Persona}

Terdapat lima dimensi dalam variabel Online Persona yaitu nickname, trust, online identification, grandiosity, dan self-esteem. Hasil mean untuk masing-masing dimensi adalah sebagai berikut:

Tabel 2. Hasil uji mean pada variabel online persona

\begin{tabular}{|l|c|}
\hline \multicolumn{1}{|c|}{ Dimensi } & Nilai Mean \\
\hline Nickname & 3,59 \\
\hline Trust & 3,78 \\
\hline Online identification & 3,44 \\
\hline Grandiosity & 3,09 \\
\hline Self-esteem & 2,97 \\
\hline
\end{tabular}

Sumber: data kuesioner diolah

Tabel menunjukkan bahwa nilai untuk mayoritas dimensi pada variabel Online Persona adalah diatas 3, kecuali untuk dimensi self esteem. Melalui hasil tersebut, dapat disimpulkan bahwa fans KPop yang menggunakan akun anonim ingin membangun impression terhadap orang-orang yang mereka follow atau orang-orang yang memfollow mereka.

Username dalam Twitter menjadi bagian penting ketika pengguna akun anonim ingin dikenal oleh pengguna lain dan mempermudah orang lain untuk mencari koneksi dengan orang lain yang memiliki minat yang sama terhadap KPop. Username digunakan sebagai presentasi diri kepada orang lain. Selain untuk memberikan impression dengan menciptakan online persona kepada orang lain, username juga memberikan pencapaian dari presentasi diri yang diinginkan.

Pada dimensi trust, pengguna akun anonim membentuk self-presentation yang diinginkan melalui aspek diri apa yang ingin mereka tutupi dan tunjukan. Mereka menggunakan akun anonim KPop untuk mengeksplorasi dirinya dengan meningkatkan interaksi dengan orang lain. Melalui hasil jawaban pada kuesioner, ditemukan jawaban yang cenderung setuju terhadap dimensi trust ketika menggunakan akun anonim.

Pembentukan self-presentation melalui online identification menunjukkan bahwa fans KPop yang berada di Twitter secara pseudonim memiliki keinginan untuk menunjukkan identitas pribadi mereka kepada followers mereka walaupun hal tersebut bukanlah suatu keharusan. Hal ini juga dapat dipahami bahwa walaupun menggunakan akun anonim, mayoritas responden menunjukkan identitas pribadinya melalui tweet mereka. Mayoritas responden tidak begitu banyak berinteraksi dengan followers mereka, namun tidak menutup kemungkinan mereka membuat tweet kehidupan pribadinya tanpa perlu adanya interaksi dengan fans KPop lain di Twitter. Hal ini menunjukkan adanya tingkat kepercayaan atau trust yang tinggi, sehingga responden memiliki keinginan untuk memperlihatkan identitas dirinya secara terbuka. Semakin seseorang lebih aktif berinteraksi secara online dengan orang-orang yang memiliki minat yang sama, semakin ia 
mendapatkan rasa percaya, dan semakin ia lebih memperlihatkan identitasnya ketika berada di siatuasi online.

Pada aspek grandiosity, ditemukan jawaban yang beragam terkait keinginan untuk memperoleh kekaguman dari user twitter lain. Reaksi, atau mendapatkan banyak followers bukanlah suatu tuntutan. Dapat diartikan bahwa mayoritas responden tidak mewajibkan dirinya untuk mencari kekaguman dari orang lain atau mencari keunikan tersendiri melalui promosi diri untuk memperbanyak followers-nya. Terlepas dari hasil tersebut, perasaan senang ketika mendapatkan feedback dari orang lain yang merupakan suatu hal yang wajar bagi para pengguna akun anonim KPop. Dapat dipahami bahwa mayoritas fans KPop yang memiliki akun anonim di Twitter tidak mementingkan pencapaian untuk memiliki followers yang banyak, tetapi dengan hanya mendapatkan reaksi dari followers mereka dapat mengurangi tingkat kegelisihan melalui grandiosity yang mengakibatkan adanya keterbukaan dalam berbagi pengalaman atau identitas mereka.

Berbeda dengan aspek lainnya, hasil menunjukkan bahwa mayoritas fans KPop dengan akun anonim di Twitter tidak memiliki self-eseem yang rendah ketika berada di situasi tatap muka, tetapi mereka merasa bahwa minat KPop mereka masih dipandang sebelah mata oleh publik, sehingga mereka mencari adanya koneksi yang memiliki minat KPop yang sama untuk meningkatkan self-esteem mereka terhadap minat mereka pada KPop. Pengguna cenderung lebih banyak memakai akun anonim sebagai bentuk privasi dan hiburan. Ini dapat dilihat dari bagaimana elemen profil, terutama username, name, deskripsi profil dan header photo menjadi elemen yang paling banyak disamarkan. Ini dapat menggambarkan bahwa masih banyak fans KPop di Indonesia yang tidak ingin memperlihatkan identitas aslinya bahwa mereka adalah fans yang aktif melakukan kegiatan fandom KPop di Twitter. Hal ini juga menggambarkan bahwa masih banyaknya anggapan bahwa minat terhadap KPop adalah sesuatu yang masih perlu ditutupi di luar fandom KPop di Twitter, sehingga menjadikan adanya anggapan bahwa fans KPop di Indonesia masih terbilang minoritas. Penggunaan Twitter sebagai sarana komunikasi dapat meningkatkan self-esteem mereka terkait dengan minat terhadap Kpop.

\section{Group Dynamics}

Terdapat empat dimensi dalam variabel Group dynamics yaitu connection, supportive interaction, affective, dan cognitive. Berikut adalah hasil yang didapatkan untuk pertanyaanpertanyaan dalam variabel ini.

Tabel 3. Hasil uji mean pada variabel group dynamics

\begin{tabular}{|l|c|}
\hline \multicolumn{1}{|c|}{ Dimensi } & Mean \\
\hline Connection & 3,37 \\
\hline Supportive interaction & 3,07 \\
\hline Affective & 4,05 \\
\hline Cognitive & 4,16 \\
\hline
\end{tabular}

Sumber: data kuesioner diolah

Pada dimensi connection, dapat dipahami bahwa skor diatas 3 menunjukkan adanya 
perasaan diterima dan mayoritas fans KPop menjalin ikatan yang kuat dengan fans KPop lainnya ketika mereka saling berinteraksi dengan dengan fans KPop lainnya di Twitter. Dari semua hal yang didapatkan melalui adanya hubungan dengan fans KPop lainnya di Twitter, mendapatkan teman baru di Twitter adalah hal yang paling banyak dirasakan oleh responden dengan nilai sebesar 4.11. Melalui penggunaan akun anonim KPop di Twitter, responden bertemu dengan fans lain yang membuat mereka lebih merasa diterima karena memiliki frame of reference yang sama. Interaksi yang termediasi oleh twitter, baik itu membahas mengenai KPop atau kehidupan pribadimembuat mayoritas fans KPop mendapat dukungan dan penghargaan akan minat mereka. Konsekuensinya, mereka menjadi lebih aktif dalam membicarakan minat mereka terhadap KPop di Twitter dibandingkan ketika berada di situasi tatap muka. Dapat dipahami bahwa fandom KPop yang ada di Twitter dapat membentuk adanya rasa solidaritas di dalamnya.

Pada dimensi supportive interaction mayoritas responden tidak selalu memberikan interaksi yang suportif kepada mutuals mereka. Supportive interaction yang ada ditunjukkan melalui tweet dan pemberianfeedback.

Hasil yang diperoleh dimensi afektif menunjukkan bahwa interaksi dengan sesama fans dapat meningkatkan perasaan bahagia dan sense of belonging. Hal ini dapat dihubungkan dengan dimensi-dimensi sebelumnya, bahwa dengan menemukan teman yang memiliki minat yang sama, dan bagaimana akun anonim dapat memberikan kebebasan bagi mereka untuk membicarakan minat tersebut, fans KPop merasakan keterlibatan emosional, kebahagiaan, dan juga rasa saling memiliki.

Pada aspek kognitif, hasil analisis mean menunjukkan kecenderungan bahwa hubungan yang terjalin di dalam fandom KPop yang ada di Twitter adalah hubungan yang kuat, dan tentunya dengan menggunakan akun anonim di Twitter dapat memberikan pengaruh positif dalam memberikan kenyamanan dalam berinteraksi secara lebih leluasa.

\section{Analisis Cross Tabulation}

Analisis crosstabs dilakukan dengan membandingkan nilai chi-square tabel dan chisquare hitung untuk mengetahui apakah ada korelasi di antara masing-masing pertanyaan. Apabila nilai chi-square tabel > chi-square hitung, maka terdapat korelasi di antara pertanyaan yang diuji, begitu juga sebaliknya. Nilai chi-square tabel ditemukan setelah menghitung $\alpha(5 \%)$ dengan nilai df yang diperoleh dari hasil crosstab.

Dari hasil crosstab dapat dilihat bagaimana self-presentation dan munculnya sense of belonging yang dimiliki oleh pengguna akun anonim Kpop memiliki hubungan yang signifikan. Hal ini kemudian dapat dipahami bahwa pengguna akun anonim yang lebih terbuka dalam mempresentasikan dirinya dengan fans KPop lain yang ditemukan di Twitter lebih banyak mendapatkan perasaan adanya saling memiliki dan ikatan yang lebih kuat dengan sesama fans Kpop.

Aspek psikologis dalam proses komunikasi pengguna akun anonim menggambarkan bahwa responden tidak selalu ingin menutupi identitas 
asli atau kehidupan pribadinya. Melalui adanya kepercayaan dengan orang lain yang baginya dapat memberikan kenyamanan dan perasaan bahwa dirinya menemukan tempat di mana ia berada (sense of belongingness), menjadikan seseorang ingin membuka diri baik mengenai minat maupun kehidupan pribadinya. Dan dengan adanya keinginan untuk terus mengoneksikan diri dengan sesamanya, menjadikan seseorang lebih merasa bahwa ikatan pertemanan yang terjalin dalam lingkungan virtual ini terasa lebih dekat dibandingkan ketika berada di lingkungan tatap muka, dan hal inilah yang kemudian dapat dipahami dari fans KPop yang menggunakan akun anonim di Twitter.

Hasil uji crosstab menunjukkan bahwa terdapat korelasi antara jenis kelamin dengan selfesteem, dan hal itu berhubungan dengan kurangnya kepercayaan diri ketika berinteraksi tatap muka dengan orang lain di dunia nyata. Selain itu, jenis kelamin jika dikaitkan dengan bagaimana low self-esteem dapat memotivasi seseorang dalam meningkatkan keinginannya untuk mencari lingkungan yang dapat memberikan rasa aman dan rasa memiliki (sense of belonging), hal tersebut menjadikan asumsi bahwa adanya hubungan antara self esteem dan perasaan memiliki (sense of belonging) adalah benar ketika melihat adanya korelasi antara jenis kelamin dan keduanya.

Terdapat korelasi antara usia dengan perasaan minat KPop yang tidak dapat diterima secara bebas. Hal tersebut memperlihatkan bahwa minat terhadap KPop masih terbilang tidak normatif dan menjadikan fans KPop lebih tertutup dengan minatnya. Selain itu, berdasarkan uji crosstab tampak bahwa terdapat korelasi antara usia dengan perasaan sense of beloinging ketika berada di fandom Twitter dengan adanya peningkatan komitmen melalui saling berbagi minat atau pengalaman dengan mutuals mereka difandom KPop Twitter.

Uji crosstab juga menunjukkan bahwa terdapat korelasi antara seseorang yang tergabung dalam multifandom di fandom KPop Twitter dengan meningkatnya rasa solidaritas selama berinteraksi dengan mutuals di fandom KPop Twitter. Terdapat korelasi antara motivasi fans KPop menggunakan akun anonim dengan bagaimana mereka ingin mencari tempat atau kelompok orang yang memiliki minat yang sama terhadap KPop. Hasil chi-square di atas, dapat dilihat bahwa satu dari tiga pertanyaan kategori trust, yaitu "Tidak bebas berekspresi k e ti $k$ a teman/kenalan/saudara di kehidupan sehari-hari mendapati akun anonim dengan perasaan lebih dihargai dan diterima terkait minat Kpop" memiliki hubungan dengan pernyataan bahwa selama berinteraksi di Twitter menimbulkan adanya perasaan lebih dihargai dan adanya dukungan terhadap minat KPop di Twitter.

Dari tiga pertanyaan mengenai commitment, yaitu "Tidak menyembunyikan identitas pribadi dengan perasaan beruntung datang ke Twitter dan berinteraksi dengan fans lain", "Berinteraksi terkait KPop dengan perasaan beruntung datang ke Twitter dan berinteraksi dengan fans lain", dan "Berinteraksi terkait kehidupan pribadi dengan perasaan beruntung datang ke Twitter dan berinteraksi dengan fans lain", diketahui bahwa adanya korelasi antara cognitive dengan tiga pertanyaan mengenai online 
identification. Hal ini menunjukkan bahwa adanya korelasi antara keterbukaan fans KPop yang menggunakan akun anonim dengan bagaimana mereka mendapatkan manfaat positif dari terbukanya interaksi dengan fans lain di fandom KPop Twitter.

Pertanyaan-pertanyaan yang berkaitan dengan grandiosity adalah "Perasaan senang ada reaksi dari followers dengan perasaan sense of belonging selama berinteraksi dengan Twitter mutuals di fandom Kpop" dan "Perasaan senang ada reaksi dari followers dengan perasaa beruntung datang ke Twitter dan berinteraksi dengan fans lain". Berdasarkan hasi uji crosstab terdapat korelasi antara grandiosity dengan kategori affective dan cognitive. Ini kemudian memungkinkan adanya anggapan bahwa fans KPop yang menggunakan akun anonim tidak semua memiliki tingkat self-esteem yang rendah, dan walaupun adanya perasaan grandiosity, tidak memungkiri adanya keinginan mereka untuk mencari kelompok yang dapat memberikan rasa kedekatan.

Melalui lima pertanyaan mengenai selfesteem, terdapat tiga pertanyaan yang memiliki korelasi dengan pernyataan bahwa fans KPop yang menggunakan akun anonim mendapatkan dukungan terhadap minat KPop di Twitter. Tiga pertanyaan tersebut adalah "Datang ke Twitter untuk mencari teman yang menyukai Kpop dengan mendapatkan dukungan dari minat KPop di Twitter" "Minat KPop tidak diterima secara bebas di interaksi tatap muka dengan mendapatkan dukungan dari minat KPop di Twitter" dan "Perasaan tidak nyaman ketika mendapati sedang fangirling/faboying dengan mendapatkan dukungan dari minat KPop di Twitter". Hal tersebut menunjukkan bahwa terdapat korelasi antara hubungan self-esteem dengan connection.

\section{Aspek Psikologis selama Berkomunikasi melalui} Akun anonim KPop di Twitter

Pengguna akun anonim KPop Twitter di Indonesia, pengguna cenderung lebih banyak memakai akun anonim sebagai bentuk privasi dan hiburan. Ini dapat menggambarkan bahwa masih banyak fans KPop di Indonesia yang tidak ingin memperlihatkan identitas aslinya bahwa mereka adalah fans yang aktif melakukan kegiatan fandom KPop di Twitter. Hal ini juga menggambarkan bahwa masih banyaknya anggapan bahwa minat terhadap KPop adalah sesuatu yang masih perlu ditutupi di luar fandom KPop di Twitter, sehingga menjadikan adanya anggapan bahwa fans KPop di Indonesia masih terbilang minoritas.

Terdapat kecenderungan bahwa fans KPop yang menggunakan akun anonim lebih sering membicarakan mengenai KPop dibandingkan kehidupan pribadinya. Akan tetapi, selama menggunakan akun anonim mereka lebih banyak berbicara dan tidak menyembunyikan identitas pribadinya. Hal ini kemudian menjadikan adanya kecenderungan bahwa penggunaan akun anonim KPop dan bagaimana mereka mendapatkan teman baru serta saling berinteraksi mengenai minat KPop-nya memberikan perasaan beruntung. Melihat kecenderungan ini, dapat dilihat bahwa penggunaan akun anonim memberikan kebebasan fans KPop untuk memperlihatkan minat KPop-nya lebih bebas dan 
mendapatkan pengaruh positif selama berkomunikasi di dalamnya.

Pada intinya, proses komunikasi dalam penggunaan akun anonim yang dilihat melalui aspek psikologis dapat menggambarkan bahwa walaupun menggunakan akun anonim, seseorang tidak selalu ingin menutupi identitas asli atau kehidupan pribadinya. Melalui adanya kepercayaan dengan orang lain yang baginya dapat memberikan kenyamanan dan perasaan bahwa dirinya menemukan tempat di mana ia berada ('where I belong'), menjadikan seseorang ingin membuka diri baik mengenai minat maupun kehidupan pribadinya. Dan dengan adanya keinginan untuk terus mengoneksikan diri dengan sesamanya, menjadikan seseorang lebih merasa bahwa ikatan pertemanan yang terjalin dalam lingkungan virtual ini terasa lebih dekat dibandingkan ketika berada di lingkungan tatap muka, dan hal inilah yang kemudian dapat dipahami dari fans KPop yang menggunakan akun anonim di Twitter.

\section{KESIMPULAN}

Adanya kecenderungan perasaan bahwa minat KPop tidak dapat diterima secara bebas ketika berada di interaksi tatap muka mendorong fans KPop untuk datang ke Twitter secara anonim. Perasaan positif yang ditimbulkan melalui penggunaan akun anonim KPop juga tidak terlepas dari bagaimana fans KPop membentuk impression dan self- presentation selama berkomunikasi di Twitter. Pembentukan selfpresentation melalui bagaimana fans KPop berkomunikasi dengan fans lain terkait minat atau kehidupan pribadi memberikan korelasi dengan munculnya perasaan positif yang dirasakan ketika fans KPop menggunakan akun anonim di Twitter.

Melalui pembentukan self-presentation tersebut dapat memberikan jawaban dari pertanyaan dari apa yang menjadi hasil yang dirasakan ketika menggunakan akun anonim. Dengan munculnya perasaan saling memiliki dan adanya perasaan ikatan kuat terhadap bagaimana seseorang menemukan kelompok yang memiliki minat yang sama menciptakan adanya perasaan bahwa akun anonim Twitter sangat membantu dalam meningkatkan self-esteem seseorang terhadap minat yang selama ini dianggap tidak normatif.

Hal ini sekaligus menjawab fandom KPop yang memiliki sifat kolektif dengan melihat adanya ikatan pertemanan yang kuat yang ditimbulkan ketika fans KPop menemukan kelompok yang saling memberikan keterlibatan emosional walaupun tidak adanya kontak fisik. Fandom KPop sebagai fandom yang memiliki ikatan kuat terhadap idola maupun sesama fans dari berbagai penjuru dunia menjadikan penggunaan media sosial penting adanya sebagai bagian dari interaksi, dan menjadikan fans KPop yang tergabung dalam Twitter lebih merasakan adanya hubungan yang kuat.

\section{DAFTAR PUSTAKA}

Attrill, Alison \& Fullwood, Chris. 2016. Applied Cyberpsychology: Practical Applications of Cyberpsychological Theory and Research. London: Palgrave Macmillan.

Boyle, Kris dan Johnson, Thomas J. 2010. Myspace 
is Your Space? Examining Self- presentation of MySpace Users. Terarsip pada www.elsevier.com/locate/comphumbeh.

Chen, Gina Masullo. 2010. Tweet This: A Uses and Gratifications Perspective on How Active Twitter Use Gratifies A Need to Connect with Others. Terarsip pada www.elsevier.com /locate/comphumbeh.

Cheung, Christy M.K, Chiu, Pui-Yee, dan Matthew K.O. Lee. 2010. Online Social Networks: Why Do Students Use Facebook? Terarsip pada www.elsevier.com/locate/comphumbeh.

Gackenbach, Jayne. 2007. Psychology and the Internet: Intrapersonal, Interpersonal, and Transpersonal Implications 2nd Edition. United States of America: Elsevier.

Heglingegard, Lena. 2016. Fandom and Communication: The Supernatural Fandom in Social Media (Project). Aarhus Univeristy. Terarsip pada http://pure.au.dk/portal-asbstudent.

Hogan, Kattie Marie. 2012. Narratives of Possibility: Adolescent Girls Constructing and Negotiating Front and Back Stage Identities Through Blogs. Terarsip pada http://digitalcommons.wayne.edu/oa_diss ertations.

Hu, C., Kumar, S., Huang, J., \& Ratnavelu, K. (2020). The predictors of users' satisfaction in an anonymous environment: the role of the negative true self. Behaviour \& Information Technology, 39(2), 213-225. https://doi.org /10.1080/0144929X.2019.1597165

Huang, J., Kumar, S., \& Hu, C. (2018). Gender differences in motivations for identity reconstruction on social network sites.
International Journal of Human-Computer Interaction, 34(7), 591-602. https://doi.org/ 10.1080/10447318.2017.1383061

Jenkins, Henry. (1992). Textual Poachers: Television dan Partisipatory Culture Studiesin Culture and Communication. New York: Routledge.

Jung, Sun. 2011. Race and Ethnicity in Fandom: Praxis-KPop, Indonesian Fandom, and SocialMedia. Terarsip pada http://journal. transformativeworks.org.

Keipi, Teo, Atte Oksanen, dan Pekka Rasanen. 2014. Who prefers anonymous self- online? A survey-based study of Finns aged 15-30 years. School of Social Sciences and Humanities University of Tampere. Terarsip pada http://www.tandfonline. com/toc/rics20/18/6? nav=tocList.

Lee, Elizabeth. 2012. KPop: Fans, Internet, and Influence. Terarsip pada https://www. academia.edu/.

Lee, Ho, dkk. 2014. Impact of Anonymity on Informatin Sharing through Internal Psychological Processes: A Case of South Korean Online Communities. Journal of Global Information Management. Terarsip pada http://aisel.aisnet.org/pacis2013/70.

Ma, X., Andalibi, N., Barkhuus, L., \& Naaman, M. (2017, May). "People Are Either Too Fake or Too Real" Opportunities and Challenges in Tie-Based Anonymity. In Proceedings of the $2017 \mathrm{CHI}$ conference on human factors in computing systems (pp. 1781-1793). http://dx.doi.org/10.1145/3025453.30259 56

Obiegbu, C. J., Larsen, G., Ellis, N., \& O'Reilly, D. 
(2019). Co-constructing loyalty in an era of digital music fandom: An experientialdiscursive perspective. European Journal of Marketing Vol. 53 No. 3, 2019 pp. 463-482. http://dx.doi.org/10.1108/EJM-10-20170754

Oh, Hyun Jung, Ozkaya, Elif, dan Robert LaRose. 2013. How Does Online Social Networking Enhance Life Satisfaction? The Relationships Among Online Supportive Interaction, Affect, Perceived Social Support, Sense of Community, and Life Satisfaction. Terarsip pada www.elsevier.com/locate/comphumbeh.

Purwanto, Erwan Agus dan Sulistyastuti, Dyah Ratih. 2011. Metode Penelitian Kuantitatif untuk Administrasi Publik dan MasalahMasalah Sosial. Yogyakarta: Gava Media.

Schumann, Sandy. 2015. How The Internet Shapes Collective Actions. Hampshire: Palgrave Macmillan.

Van Dijk, Jan. 2006. The Network Society. 2nd Edition. London: SAGE Publications Ltd.

Wallace, Patricia. 1999. The Psychology of The Internet. Inggris: Cambridge University Press.

Williams, J. Patrick. 2006. Authentic Identities: Straightedge Subculture, Music, and the Internet. Journal of Contemporary Ethnography, Vol. 35, No. 2. Sage Publications.

Williams, R. (2015). Post-object fandom: Television, identity and self-narrative. Bloomsbury Publishing USA. 